\title{
Clinical, para-clincal and outcomes of diabetes ketoacidosis in Vietnam national hospital pediatrics
}

\author{
Nguyen Thi Thu Nga ${ }^{2}$, Nguyen Phu Dat ${ }^{1}$, Vu Chi Dung ${ }^{2}$, Bui Phuong Thao ${ }^{2}$ \\ From 8th APPES Biennial Scientific Meeting \\ Darwin, Australia. 29 October - 1 November 2014
}

Diabetic ketoacidosis (DKA) is a serious complication of diabetes mellitus that occurs when your body produces high levels of blood acids called ketones.

\section{Objective}

This study aimed at describing some characteristics of clinical and commenting outcomes of the treatment for DKA in children with diabetes mellitus type 1 (DM1) in Vietnam National Hospital of Pediatrics from 2007 to 2012.

\section{Methods}

Description retrospective and prospective on all patients previously diagnosed of DM1 or newly diagnosed of DM1 with DKA.

\section{Results}

On average: each year, patients with DKA were admitted. $72 \%$ of these cases were first presentation with diabetes. Up to $36 \%$ of cases had misdiagnosis for other diseases. Clinical: dehydration 100\%; $92 \%$ altered consciousness; vomiting $72 \%$; thirsty $72 \%$; weight loss $78 \%$. The clinical presentation of DKA in patients who the newly diagnosed of DM1 was more severe than that in preciously diagnosed patients. The risk factors: $64 \%$ infection for all; $57.1 \%$ non-compliance with treatment for patients being treated insulin before. Laboratory: Blood glucose $36.8 \pm 13.5 \mathrm{~mol} / \mathrm{l}$ (from 14 to $70 \mathrm{~mol} / \mathrm{l}$ ). Severe and moderate acidosis was seen in $56 \%$. Abnormality of sodium levels were found in $11 / 25$ patients (44\%), of which only $3 / 25$ patients actually decreased serum sodium (adjusted sodium); hyperkalemia in 6/25

Vietnam National Hospital of Pediatrics, Hanoi, Vietnam

Full list of author information is available at the end of the article patients (24\%). The time of infusion insulin was $18.9 \pm$ 27.56 hours. Average time replacing fluid was $37.7 \pm 21.1$ hours. The duration of ketonuria was $37.9 \pm 17.5$ hours. Patients were alert after $12.04 \pm 11.52$ hours.

\section{Conclusion}

DKA is a complex disordered metabolic state characterized by hyperglycemia, ketoacidosis, and ketonuria. The goal of treatment is to correct the high blood glucose level with insulin. Another goal is to replace fluids lost through urination, loss of appetite, and vomiting.

\section{Authors' details}

${ }^{1}$ Hanoi Medical University, Hanoi, Vietnam. ${ }^{2}$ Vietnam National Hospital of Pediatrics, Hanoi, Vietnam.

Published: 28 April 2015

\section{doi:10.1186/1687-9856-2015-S1-P13}

Cite this article as: Nga et al:: Clinical, para-clincal and outcomes of diabetes ketoacidosis in Vietnam national hospital pediatrics.

International Journal of Pediatric Endocrinology 2015 2015(Suppl 1):P13.

Submit your next manuscript to BioMed Central and take full advantage of:

- Convenient online submission

- Thorough peer review

- No space constraints or color figure charges

- Immediate publication on acceptance

- Inclusion in PubMed, CAS, Scopus and Google Scholar

- Research which is freely available for redistribution 